\title{
Knowledge-sociological and information-sociological aspects of knowledge organization ${ }^{(1)}$
}

\author{
H. Peter OHLY \\ ISKO, Prinzenstr. 179, D- 53175 Bonn \\ president@isko.org
}

\begin{abstract}
Resumen
Desde hace cincuenta años, la organización del conocimiento -el desarrollo de conceptos científicos y su estructuración- se entiende como un problema lógico y, por tanto, universal. Los enfoques tradicionales ven las áreas del conocimiento como dadas naturalmente y regidas por un crecimiento orgánico. El constructivismo ha traido un cambio de paradigma, que contempla la organización del conocimiento como una convención social; $y$, consecuentemente, considera escépticamente la existencia de estándares universales. Simultáneamente, se ha producido en las ciencias un interés más intenso sus fundamentos históricos y sociológicos; y en la filosofía de la ciencia ha ganado en importancia la reconsideración de diferentes relativizaciones. En este artículo, se discuten vías de las posiciones sociológicas clásicas y se trazan sus implicaciones en la comprensión de la información y el conocimiento, así como para la ciencia de la organización del conocimiento, atendiendo especialmente a las objeciones que plantean a las perspectivas clásicas.
\end{abstract}

Palabras clave: Información. Conocimiento. Organización del Conocimiento. Condicionantes históricos. Condicionantes sociológicos. Sociología.

\section{The natural representation of knowledge organization}

\subsection{Knowledge as nature}

In ancient times, as well as in the Middle Ages (Scholastic), knowledge was seen as something like nature that can be crystallized and developed inevitably from fundamental principles of knowledge. Typically, knowledge was represented as a tree (Tree of knowledge), which derives branches and twigs and thus appends organically new knowledge to old knowledge. Typical representations are found in Raimundus Lullus (see Figure 1, next page; CAS undated) or in Diderot's Encyclopedia (D'Alembert, 1751).

But knowledge has not been seen value-neutral. The alchemists, wise women, or even the pur-

\begin{abstract}
50 years ago knowledge organization, the development of scientific concepts and arrangements, has been seen as a logical and thus universal problem. Older approaches accordingly see areas of knowledge as naturally given and organically grown. At latest with the constructivism has entered a 'turn', which sees knowledge organization as a social convention and accordingly regards universal standards skeptical. Simultaneously in the sciences came up a stronger concern with historical and sociological studies of its foundations and in philosophy of science the return to different kinds of relativizations has gained more importance. In this paper, some single classical sociological positions are discussed, conclusions are drawn for knowledge and information as well as for science and knowledge organization and objections are designated.
\end{abstract}

Keywords: Information. Knowledge. Knowledge organization. Historical aspects. Sociological aspects. Sociology.

suit of final knowledge, the purpose of creation and its control as Doctor Faustus tried it about, were regarded as heretical or evil. As it is well known from the writings of the Bible, Adam and Eve had to pay for it, and were expelled from the Garden of Eden (see Figure 2, next page) (2).

\subsection{Knowledge as a spatial order}

Quite in the classical tradition is the arrangement of literature in a static spatial order, which is to reflect the content and make it easily accessible: The subject catalog is not only be grasped but also be patrolled (see Figure 3 and 4 ). But as requirements of the library, the librarian, and the user must be harmonized not only theoretical contexts have to be considered (Leitner/Zwanziger 1985). 


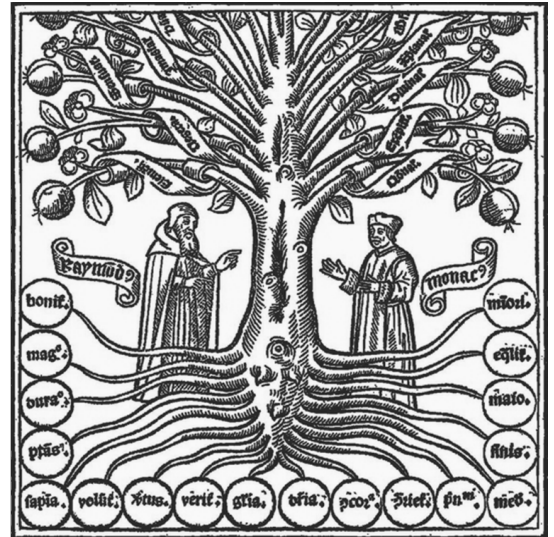

Figure 1. Ramon Lull's "Arbor scientie"

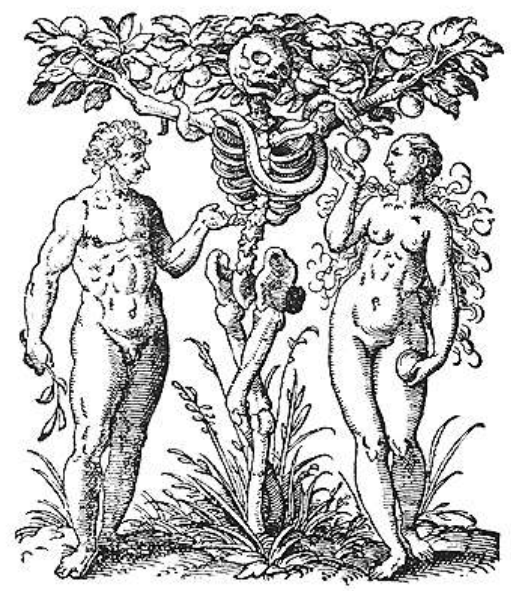

Figure 2. Jost Amman: Adam and Eve with the Tree of Knowledge as Death (1587, Jacob Ruegg's De conceptu et generatione hominis) (3)

\subsection{Knowledge as virtual organization}

Virtual knowledge organization -as it started with catalogues, but is now familiar with machine readable data stocks and hyperlinked information in the Web- is per se independent from the location and generic evolvement of the sources. In the virtual catalogs, search engines (eg. Boolean search) or alphabetical listings are predominant indeed. It is in so far context free, but has very soon been accompanied by references to its surroundings, be it keywords in context, upper levels or relations. There are also attempts to allow a spatially ordered, systematic access, eg. at the (now defunct) English Institute gateway to subject catalogs and the European research system for the subject guide Renardus. Here, a scheme has been developed that visualizes the underlying DDC (Dewey Decimal Classification) spatially (Figure 5). For administration purposes the UDC Master Reference File is available in different interactive visualization modes by Magnaview software, eg. as a node tree whose tags can be connected with a Google search (4).

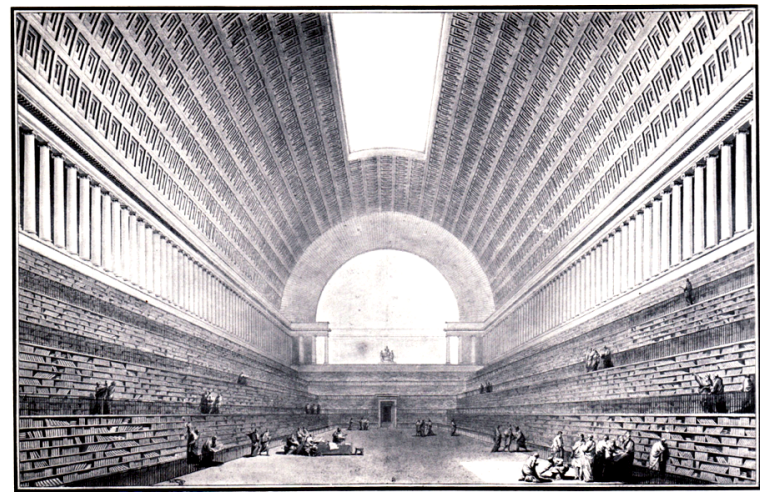

Figure 3. Étienne-Louis Boullée, Project for the National Library Paris (1785) (7)

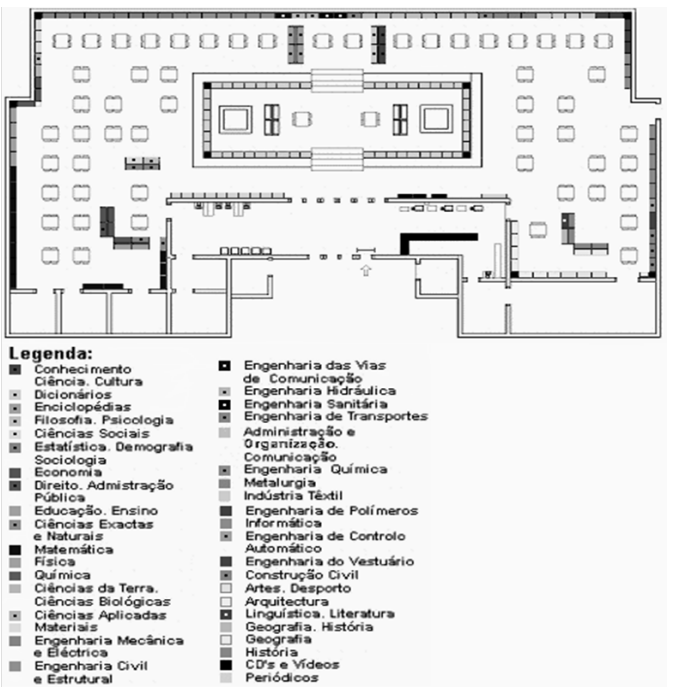

Figure 4. Spacial Arrangement According to Universal Decimal Classification System (UDC) at the University Library in Guimarães, Universidade do Minho, Portugal (8)

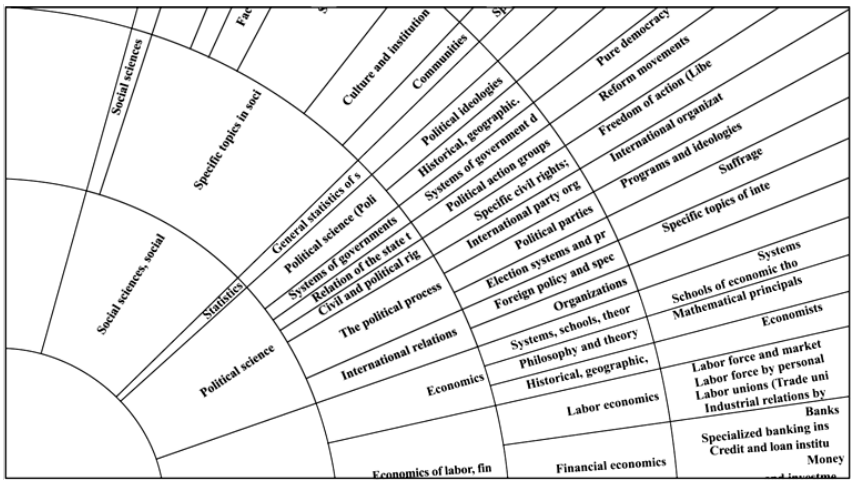

Figure 5. Cross-browsing European Subject Gateways Via a Common Classification System $(D D C)(9)$ 
The currently popular word clouds, however, are in their structure dynamically aligned to the frequencies of the data source at hand (eg. literature) and thus lead over to the following social approaches. They are quite reputable applicable if they reflect quantity distributions and associative distance of literature holdings in an at least two-dimensional image - see Figure 6; cf. Tree maps (5) - In general, the size of the (key) words then corresponds to the frequency of distribution and the proximity of the words cooccurrence (6).

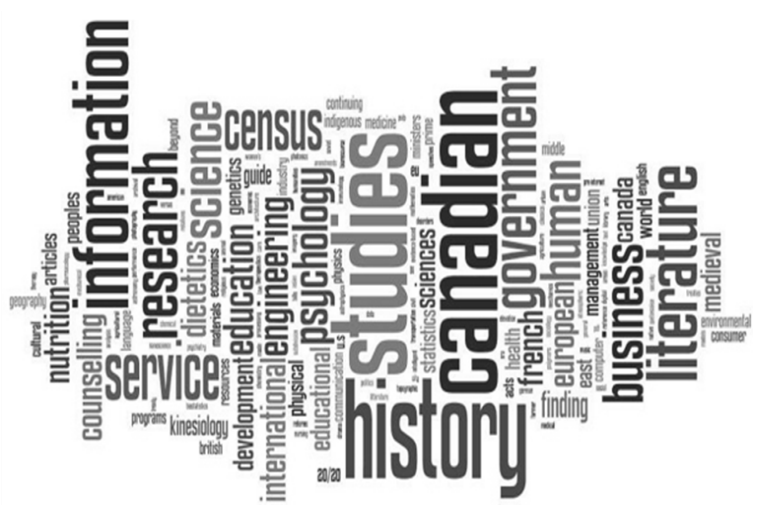

Figure 6. Word cloud of library materials. McGill Library, Mclennan Library Building, 3459 McTavish Street, Montreal, Quebec H3A 1 Y1 (10)

\section{Philosophy of science, sociology of science and sociology of information}

To understand more different kinds of arrangement of knowledge and their pointers to it, we have to look at the philosophical and sociological analysis of the conditions for treating and understanding knowledge. An integral part of philosophy and scientific theory is the theory of knowledge or epistemology. Some questions to illustrate this area are (Wikipedia Contributors, 2013a; emphasis added by the author):

- How do we perceive our environment?

- Unconscious filtering of sensory impressions

- Storage of sensations in the brain

- What structures exist in a given brain to sort sensory impressions and convert them into real knowledge?

- How to form concepts and categories of thought?

- How and one can even gain objective knowledge?

- What methods are there to check findings?
- How has the biological evolution improved the processing of sensory impressions and the gaining of insight?

Sociology of knowledge, although following on the philosophy of science, however, has slightly different oriented topics (Wikipedia Contributors, 2013b; emphasis added by the author): it deals with the creation, dissemination, use and preservation of knowledge within groups, communities and societies; and considers that knowledge and thinking is socially determined.

The differences between scientific theory and sociology of science can be worked out following the lines drawed in Table I:

\begin{tabular}{ll}
\hline Philosophy of Science & Sociology of Science \\
\hline science is uniform & sciences are divided \\
\hline uniform knowledge & $\begin{array}{l}\text { different knowledge } \\
\text { depending on the position } \\
\text { and context }\end{array}$ \\
\hline mainstream knowledge & $\begin{array}{l}\text { competitions of } \\
\text { knowledge }\end{array}$ \\
\hline $\begin{array}{l}\text { knowledge is value- } \\
\text { neutral }\end{array}$ & $\begin{array}{l}\text { interests determine } \\
\text { knowledge }\end{array}$ \\
\hline
\end{tabular}

Table I. Differences between Philosophy and Sociology of Science

Information sociology can then be seen as a more concrete sociology of knowledge specialized in information and documentation processes. Wersig (1973) defines information as a reduced uncertainty through communication. Similarly Kuhlen (1995) understands information as "knowledge in action".

It can be stated as a shared denominator, that information is a social phenomenon and accordingly should be accessible to sociological research. Wersig lists more or less the following areas:

- Empirical research: need for information analysis, information structure analysis, diffusion analysis, benefit analysis, and information behavior

- Critical research: function of scientifictechnical systems, capitalism in the information area, information systems for critical public, and commodification of knowledge

\section{Sociological knowledge positions}

Plato is considered to be a philosopher who applied early sociological considerations, includ- 
ing the allegory of the cave (Platon, s. d.), where he points out that we humans see only a silhouette ("ideas") of real-life contexts and thus are subject to illusions in perception. If we would see all the real relationships, then we could hardly endure this knowledge of the truth ("wisdom") (11).

Max Weber (2010) is one sociologist who shows with his analysis of the emergence of the Protestant ethic, sociological lines. In the Middle Ages religion was determining what was worth knowing. The knowledge was used for deeper religious knowledge. With the onset of modern times this knowledge became more self confident and led to independence, if not to say to scientification of religious beliefs. For Weber himself religion is not in question, but he draws a clear distinction between scientific knowledge and religious faith (12).

The sociologist Karl Mannheim (1929), faced with the ideological discussions of his time (emphasis by the author)

takes no theoretical assertion as an absolutely valid way, but reconstructs the original positions from which the world has been revealed such and such, and tries to understand the totality of the perspective views from the totality of the process.

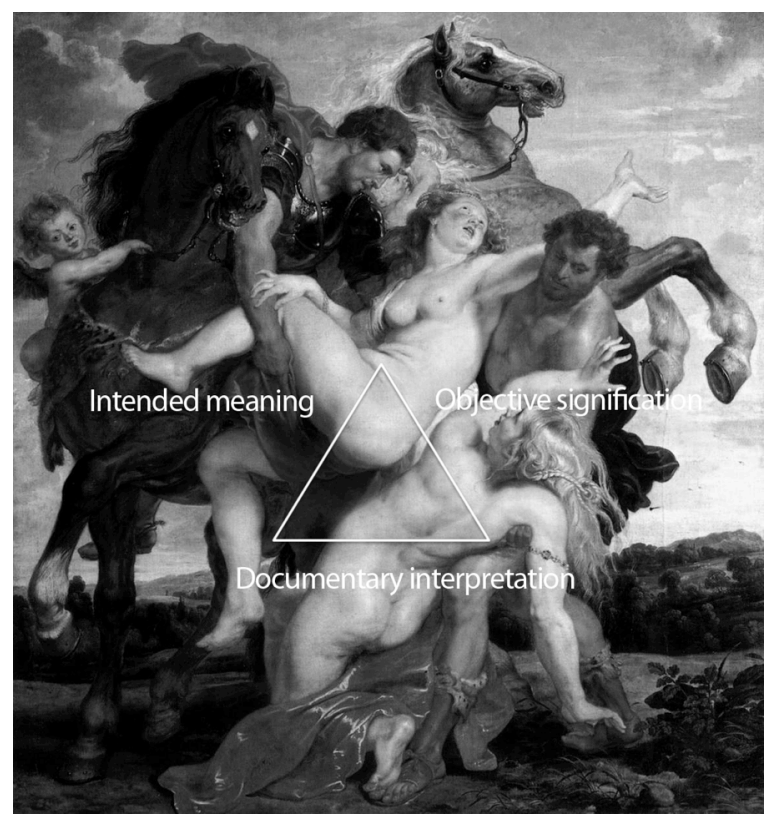

Figure 7. Varieties of Meaning. Example: Rubens: Rape of the Daughters of Leucippus, 1618, Alte Pinakothek Munich (14)

$\mathrm{He}$ is the major founder of a so-called "sociology of knowledge". All cultures, including subcultures have their specific themes and modes of expression (eg. architectural styles) and must be understood out of their specific situation. He hoped for an ability of understanding between different ideologies. He scrutinized several types of signification of a human artifact (Figure 7): intended meaning, objective signification, documentary interpretation (13).

In the tradition of Karl Marx, the Frankfurt School took up such programmatics also. Adorno and Horkheimer argued against a senseless culture industry, which tends to offer culture, only because of the economic profit, and does not stop at plagiarism (Adorno 1970). Our familiar 'Copy and Paste' would hardly have been feasible for them and scientific plagiarism, inaccuracy and redundancy seem to justify them.

The Frankfurt sociologist Habermas tries to uncover the mechanisms of communication by enabling a power-free dialogue. Inter alia, he differentiates (Knoblauch 2005, Habermas 1981) among:

- Instrumental action: The aim of manipulating the external world of objects; actions, that selects appropriate means for the purpose of manipulating things / making nature available.

- Strategic action: Acting according to the means-end schema, but not only based on objects but also on other actors (such as in game theory).

- Dramaturgical action: The goal of selfpresentation.

- Norm-based activities: Grounded on the selfevident validity of norms (15).

Similarly, the French structuralist Bourdieu acts on a kind of field theory of man. In his habit and resources, his social capital is manifested, which he uses at the crucial moment, but from which he also cannot refrain readily (Bourdieu, 1982).

In parallel, the symbolic interactionism of Berger and Luckmann (1969) is to be set. Especially in language, symbolic meanings of experienced objects and situations that can only be communicated with a meaning within the respective (linguistic) community are manifested. Examples may include the respective iconographies in the religions but as well specialized terms, illustrations and citations in science.

\section{Information technology and sociological perspectives}

Morris (1988) develops a theory of signs, which, in addition to the semantics (cf. aboutness), also gives to syntax (cf. meaningfulness) and pragmatics (cf. fruitfulness) an important role in the interpretation of characters. Shannon (1976) 
developed a measurement method to determine the information content (in the sense of eliminated uncertainty) and the redundancy of information on the basis of above or below average usage frequency of characters (16).

In so-called Science and Technology Studies, Knorr-Cetina (1984), but also Latour and Wolgar, examined the working methods of high-tech research laboratories. They show that here the knowledge is very specialized and has become independent with respect to a holistic view. Only the opaque interaction in a highly specialized context allows the final high-tech good. An outsider is not able to understand these different ways of working. One therefore speaks also of a "knowledge factory".

\begin{tabular}{lllll}
\hline Theoretican & Concept & Message & Implication for Knowledge & Implication for Science \\
\hline Platon & Idee & Insight is biased & Values are implicit & $\begin{array}{l}\text { Insight in nature is } \\
\text { more important than } \\
\text { consens }\end{array}$ \\
\hline Weber & $\begin{array}{l}\text { Value free } \\
\text { science }\end{array}$ & $\begin{array}{l}\text { Science and ethics have } \\
\text { to be separated }\end{array}$ & $\begin{array}{l}\text { Knowledge causes } \\
\text { bureaucracy and power }\end{array}$ & $\begin{array}{l}\text { Science cannot justify } \\
\text { value judgments but } \\
\text { only show } \\
\text { consequences }\end{array}$ \\
\hline
\end{tabular}

\begin{tabular}{|c|c|c|c|c|}
\hline Mannheim & $\begin{array}{l}\text { Sociology of } \\
\text { knowledge }\end{array}$ & $\begin{array}{l}\text { Ideologies can by } \\
\text { interpreted by their social } \\
\text { condition }\end{array}$ & $\begin{array}{l}\text { By revealing the } \\
\text { background a symbiosis is } \\
\text { possible }\end{array}$ & \\
\hline Adorno & Alienation & Interests are manipulated & $\begin{array}{l}\text { External interests have to } \\
\text { be detected and prohibited }\end{array}$ & \\
\hline Habermas & Discourse & $\begin{array}{l}\text { Domination-free } \\
\text { communication is } \\
\text { possible }\end{array}$ & $\begin{array}{l}\text { Positions have to be } \\
\text { accepted as justified }\end{array}$ & \\
\hline $\begin{array}{l}\text { Berger/ } \\
\text { Luckmann }\end{array}$ & Construction & $\begin{array}{l}\text { Everyday usage of signs } \\
\text { comprises common } \\
\text { systematic interpretations }\end{array}$ & $\begin{array}{l}\text { Phenomenological view } \\
\text { helps in interpreting; } \\
\text { importance of socialization }\end{array}$ & \\
\hline Bourdieu & Field/Habitus & $\begin{array}{l}\text { Actors are determined by } \\
\text { context and heritage }\end{array}$ & $\begin{array}{l}\text { Different knowledge is } \\
\text { activated, according to field }\end{array}$ & $\begin{array}{l}\text { Scientific positions are } \\
\text { symbolic capital }\end{array}$ \\
\hline Morris & Semiotics & $\begin{array}{l}\text { Syntagmatic, semantic } \\
\text { and pragmatic } \\
\text { dimensions of signs }\end{array}$ & Inherent grammar/esthetics & $\begin{array}{l}\text { Generative grammar } \\
\text { for text production }\end{array}$ \\
\hline Shannon & Enthropy & $\begin{array}{l}\text { Information load is } \\
\text { determined by probability } \\
\text { of occurrence }\end{array}$ & $\begin{array}{l}\text { Distinctiveness of languge } \\
\text { systems }\end{array}$ & $\begin{array}{l}\text { Economic application } \\
\text { of sign strings }\end{array}$ \\
\hline McLuhan & $\begin{array}{l}\text { Gutenberg- } \\
\text { Galaxis }\end{array}$ & $\begin{array}{l}\text { The medium is the } \\
\text { message }\end{array}$ & $\begin{array}{l}\text { New media enable new } \\
\text { social changes and } \\
\text { countermovements }\end{array}$ & \\
\hline Bell & $\begin{array}{l}\text { Postindustrial } \\
\text { society }\end{array}$ & $\begin{array}{l}\text { Knowledge is an } \\
\text { additional (economical) } \\
\text { production factor }\end{array}$ & & $\begin{array}{l}\text { Dependence of society } \\
\text { from science }\end{array}$ \\
\hline Beck & $\begin{array}{l}\text { Risk society / } \\
\text { modernity }\end{array}$ & $\begin{array}{l}\text { Technology has produced } \\
\text { new risks }\end{array}$ & & $\begin{array}{l}\text { Science can handle } \\
\text { risks }\end{array}$ \\
\hline Castells & $\begin{array}{l}\text { Network } \\
\text { society }\end{array}$ & $\begin{array}{l}\text { Nots in a network } \\
\text { become hubs of power }\end{array}$ & Domination of ITC centers & Knowledge divide \\
\hline $\begin{array}{l}\text { Knorr- } \\
\text { Cetina }\end{array}$ & Big science & $\begin{array}{l}\text { Knowledge is produced in } \\
\text { specialized centers }\end{array}$ & & $\begin{array}{l}\text { Science needs fund } \\
\text { allocation and is non- } \\
\text { transparent }\end{array}$ \\
\hline
\end{tabular}

Table II. Theoretical Concepts and their Implications (17) 
When Hjørland (2013) claims for an understanding of the science itself when trying to classify it, he refers to this highly specialized scientific procedures, but at the same time depicts the limitations of information scientists.

McLuhan (2011) highlights the importance of the form of media as content generating end in itself. With the term "information society" Bell (1973) and many others, such as Beck (1988) or Castells (2001) describe the end of the manufacturing industrial society and the dominance of communications technology, globalization and environmental problems in modern developments. From this, new power centers of knowledge and the helplessness of individuals arise. Thus, fashion and power are realities that cannot be neglected when establishing and maintaining information systems and when instructing knowledge organization fundamentals (Knight, 2008).

Weizenbaum, the detractor of artificial intelligence $(1986,2008)$, comes in response thereto, in so far as he places human values higher than technical feasibility and in doubt demands to provide technical waiver and to develop substantial responsibility instead (Hoffman 2008; Raghuramaraju 2008).

\section{Summary and Conclusion}

Plato turns out that we only have ideas but are far away from knowledge (in the sense of wisdom; cf. Table II). Max Weber draws a clear distinction between knowledge and values. Mannheim, Adorno and Habermas see misconceptions as objectively discoverable. Berger and Luckmann, but also Bourdieu, Shannon and Morris define meaning depending on contexts of action and practical use. Postmodernism and laboratory studies point to the productivity and autonomy of technological knowledge, causing Weizenbaum to a stronger demand for responsibility. The general conclusion can be drawn that knowledge is not intersubjectively selfevident as such. But rather, the structure of knowledge can be objectively worked out.

For information work, it can be concluded then that information should not be offered as an evaluative outcome but in its structure. Examples may include facets (that allow many attribute combinations), descriptive terminology, concept maps, or also "Onomantik". The latter was suggested by Fred Riggs (1981), in the way that you should first be clear about a concept that is associated with a word (or a word in a context), then you should find its possible definition(s) and only finally you should look for a name.
Hjørland (2013) proposes an Activity Theory as theoretical basis for information work:

The most important issues in the criticism of empiricism, rationalism and "positivism" probably are the neglecting of knowledge as a social and historical product made to serve certain purposes and interests and by implication the need [... to ...] reconsider knowledge claims in the light of new purposes, conditions and interests.

For practical classification work he proposes a domain-analytic view, where only the cooperation with subject scientists will result in applicable and accepted knowledge organization systems. As he says (Hjørland, 2013): "The difference between a good and a bad classification is that the good classification reveals deep insight concerning the possible choices and dilemmas and is well argued."

\section{Notes}

(1) This article is an amended English version of a talk given in German on the 13th German ISKO conference 2009 in Bonn (http://www.isko-de.org/data/uploads/Ohly -WO2009.pdf; cited links reflect the state 15/08/2013).

(2) Concerning modern interpretation the fall of man is meant as a misconduct of cognition and not of sexual behaviour (http://www.bibelwissenschaft.de/wibilex/das -bibellexikon/lexikon/sachwort/anzeigen/details/suenden fall-3/ch/869e6b14af1a81470645dc665b5f190a/).

(3) Source: http://ars-anatomica.blogspot.de/2010_06_01 _archive.html.

(4) http://www.magnaview.com/udc-viewer.html.

(5) http://www-958.ibm.com/software/data/cognos/manye yes/page/Treemap.html.

(6) This order is a dynamically generated, which is determined by the application. However (definitely needed) design options must be taken into account (such as color, font, values, language processing, etc.), otherwise they may lead to misinterpretation or at least to overinterpretations.

(7) Source: http://hebemedia.squarespace.com/storage/blog -images/art/2010-08-perverse-library/perverseboullee.jpg

(8) Source: http://www.sdum.uminho.pt/Default.aspx?tabid $=1$ \&pageid=243\&lang=en-US.

(9) Source: http://www.emeraldinsight.com/fig/2630210104 004.png. See: Koch et al, 2001.

(10) Source: retrieved in 2009 from the Internet, no longer detectable.

(11) Here some correspondence might be given to the fall of man in the Bible (see above).

(12) Here again we can see a doubt in final understanding of world truth.

(13) Related to information processes, this means that scientific interest, overt content, as well as formal characteristics should be met and distinguished, where the first is obviously the most difficult and variable.

(14) Source: http://uploads4 wikipaintings.org/images/peterpaul-rubens/rape-of-the-daughters-of-leucippus.jpg; as 
interpretation, cf. http://www1.umassd.edu/euro/2011 papers/wise.pdf or http://www.mahagoni-magazin.de/ malerei/rubens-\%E2\%80\%9Araub-der-tochter-des-leuki ppos-\%E2\%80\%93-fleisch-und-wille-um- 1618 .

(15) When reviewing scientific endeavors this might be a kind of interpretation framework.

(16) Generally Bibliometrics apply similar principles when interpreting scientific outcome.

(17) Excerpt from a summary for a seminar on Knowledge and Information Sociology of the author, Univ. Bonn 2008.

\section{References}

Adorno, Theodor W. (1970). Ästhetische Theorie. Frankfurt am Main: Suhrkamp.

Beck, Ulrich (1988). Risikogesellschaft: Auf dem Weg in eine andere Moderne., Frankfurt am Main: Suhrkamp.

Bell, Daniel (1973). Die nachindustrielle Gesellschaft. Frankfurt am Main: Campus.

Berger, Peter L.; Luckmann, Thomas (1987). Die gesellschaftliche Konstruktion der Wirklichkeit: Eine Theorie der Wissenssoziologie. Frankfurt/Main: Fischer Taschenbuch Verlag. (Erstausg.: 1969).

Bourdieu, Pierre (1982). Die feinen Unterschiede: Kritik der gesellschaftlichen Urteilskraft. Frankfurt am Main: Suhrkamp.

CAS (Center for Advanced Studies LMU) (undated(. Ordnungen des Wissens - Raimundus Lullus' "Baum des Wissens" im Signet des CAS. http://www.en.cas.unimuenchen.de/about_us/cas_emblem/index.html (15/08/ 2013).

Castells, Manuel (2001). Der Aufstieg der Netzwerkgesellschaft: Das Informationszeitalter 1, Leverkusen: Leske + Budrich Verlag.

d'Alembert, Jean-Baptiste le Rond (1997). Einleitung zur Enzyklopädie von 1751 (= Philosophische Bibliothek. Bd. 473): Durchgesehen und mit einer Einleitung herausgegeben von Günter Mensching. Hamburg: Meiner.

Gerald M. Hoffman (2008). Ethical Challenges for Information Systems Professionals. II Nemati, Hamid (2008).191-199.

Habermas, Jürgen (1981). Theorie des kommunikativen Handelns. (2 Bände). Frankfurt am Main: Suhrkamp.

Hjørland, Birger (2013). Theories of knowledge organization, Theories of knowledge. // Knowledge Organization. 40-3, 169-181.

Knight, John (2008). Ethics and $\mathrm{HCl}$. I // Nemati, Hamid R. (2008). 231-237.

Knoblauch, Hubert (2005). Wissenssoziologie. Konstanz: Verlag UTB/UVK

Knorr-Cetina, Karin (1984). Die Fabrikation von Erkenntnis: Zur Anthropologie der Naturwissenschaft. Frankfurt am Main: Suhrkamp.

Koch, Traugott; Neuroth, Heike; Day, Michael (2001). Renardus: Cross-browsing European subject gateways via a common classification system (DDC). http://www. ukoln.ac.uk/metadata/renardus/papers/ifla-satellite/iflasatellite.html (15/08/2013).

Kuhlen, Rainer (1995). Informationsmarkt: Chancen und Risiken der Kommerzialisierung von Wissen. Konstanz: UVK Universitätsverlag.

Leitner, Hans; Zwanziger, Ronald (1985). Die Buchaufstellung im Spannungsfeld von Bibliothek, Bibliothekar und Benützer. Biblos-Schriften 128. Wien: Vereinigung Österreichischer Bibliothekare.

McLuhan, Marshall (2011). Das Medium ist die Massage: Ein Inventar medialer Effekte. Stuttgart: Tropen bei KlettCotta.

Morris, Charles William (1988). Grundlagen der Zeichentheorie, Ästhetik der Zeichentheorie. Frankfurt a.M.: Fischer.

Nemati, Hamid R. (2008). Information security and ethics: concepts, methodologies, tools and applications, 6 vols. Hershey, PA: Information Science Reference. http://bookre.org/reader?file=706238 (15/08/2013).

Platon. Politeia. Kap. 1. Projeckt Gutenberg-DE, 1999. http://gutenberg.spiegel.de/buch/4885/1 (15/08/2013).

Raghuramaraju, A. (2008). Computer Ethics: Constitutive and Consequential Morality. // Nemati, Hamid R. (2008). 3084-3093

Riggs, Fred Warren (1981). Interconcept report: A new paradigm for solving the terminology problems of the social sciences. Paris: Unesco.

Shannon, Claude E.; Weaver, Warren (1976). Mathematische Grundlagen der Informationstheorie. München: Oldenbourg.

Weber, Max (2010). Die protestantische Ethik und der Geist des Kapitalismus, Vollständige Ausgabe. Edited and introduced by Dirk Kaesler, 3. durchgesehene Aufl. München: C.H. Beck.

Weizenbaum, Joseph (1986). Ohne uns geht's nicht weiter: "Künstliche Intelligenz" und Verantwortung der Wissenschaftler. // Blätter für deutsche und internationale Politik. 31 (1986) 1037-1045.

Weizenbaum, Joseph (2008). Wir gegen die Gier. // Süddeutsche Zeitung. (08.01.2008). http://maxen.de/ Weizenbaum/SZ-Wir-gegen-die-Gier.html.

Wersig, Gernot (1973). Informationssoziologie: Hinweise zu einem informationswissenschaftlichen Teilbereich, Frankfurt am Main: Athenäum.

Wikipedia Contributors (2013a). Erkenntnistheorie. // Wikipedia. Wikimedia, 2013. http://de.wikipedia.org/wiki/ Erkenntnistheorie (15/08/2013).

Wikipedia Contributors (2013b). Wissenssoziologie . // Wikipedia. Wikimedia, $2013 . \quad$ http://de.wikipedia. org/wiki/Wissenssoziologie (15/08/2013).

Enviado: 2013-07-28. Segunda versión: 2013-08-20. Aceptado: 2013-08-21. 
